\title{
Intraosseous lipoma: a case report
}

Carolina Baltera ${ }^{\mathrm{a}}$, Cristóbal Araya ${ }^{\mathrm{b}, \mathrm{c}}$, Juan Rebolledo ${ }^{\mathrm{b}}$, Alfonso Muñoz $^{\mathrm{d}}$

\section{ABSTRACT}

OBJECTIVE: The objective of this report was to demonstrate main clinical and histopathologic intraosseous mandibular lipoma features by taking a look at a specific case

CASE DESCRIPTION: A case of intraosseous lipoma in the anterior jaw of a 27 -year-old woman is reported.

CONCLUSION: The treatment of choice was surgical enucleation of the lesion, since recurrences have not been reported in the literature.

Keywords: adipocytes; lipoma; mandible.

\section{Relato de lipoma intra-ósseo}

\section{RESUMO}

OBJETIVO: O objetivo deste relato foi demonstrar as principais características clínicas e histopatológicas do lipoma mandibular intraósseo examinando um caso específico.

RELATO DO CASO: Um caso de lipoma intraósseo na mandíbula anterior de uma mulher de 27 anos é relatado. CONCLUSÃO: O tratamento de escolha foi a enucleação cirúrgica da lesão, uma vez que as recidivas não foram relatadas na literatura.

Palavras-chave: adipócitos; lipoma; mandíbula.

\footnotetext{
${ }^{a}$ Radiology Services, School of Sciences, Universidad Mayor, Santiago, Chile

- Diagnostic Service, School of Sciences, Universidad Mayor, Santiago, Chile

${ }^{\mathrm{c}}$ Head and neck department. Instituto nacional del cancer, Santiago, Chile

dental Surgeon, Universidad Mayor, Santiago, Chile
} 


\section{INTRODUCTION}

Lipoma is a benign tumor presenting mature adipose tissue, without atypias. Its frequency in the oral cavity ranges from $1 \%$ a $4.4 \%[1,2,3]$. Its most common location is subcutaneous but can also be found in bones and muscles.

Etiology of this lesion is unclear, in long bones, some authors have related it to nutritional problems and strokes. These same causes may result in the presence of this lesion in the mandible, where the inferior dental artery is the only irrigation source, which is why blocking it may cause infarction areas where fat cells accumulate and give rise to a lipoma. Trauma or mechanical factors that increase venous pressure are also considered as possible etiologic factors in the development of these lesions [2,6,7]. Other authors also indicate that lipomas correspond to final stages of infectious or inflammatory processes [6].

According to literature, Intraosseous lipoma frequency is less than $0.1 \%$ in osseous tumors $[6,7]$. In long bones, it is most commonly found in the Metaphysis, followed by the epiphysis or diaphysis areas. Other affected bones include the hilum, sacrum, vertebrates and skull bones. The objective of this report was to demonstrate main clinical and histopathologic intraosseous mandibular lipoma features by taking a look at a specific case.

\section{CASE REPORT}

Female patient, 27 years old, with no morbid history, consults orthodontic treatment. A panoramic radiographic examination is performed, showing a partially corticalized, radiolucent, oval shaped area with defined limits, located in the anterior section with respect to teeth $4.1,3.1,3.2$, 3.3 (Figure 1). No signs or symptoms associated with the injury were presented. The teeth in relation to the injury were vital. Cone beam computed tomography (CBCT) exam was requested, which showed a $2 \mathrm{~cm}$ x $3 \mathrm{~cm}$ hypodense lesion, presenting hyperdense sclerotic osseous tissue in the peripheral area. The diagnostic hypothesis was a traumatic osseous cyst (Figure 2).

Lesion excision was performed through a biopsy. A histopathological study showed fat cells with a fibrous connective tissue capsule, characteristics compatible to an intraosseous lipoma (Figure 3).

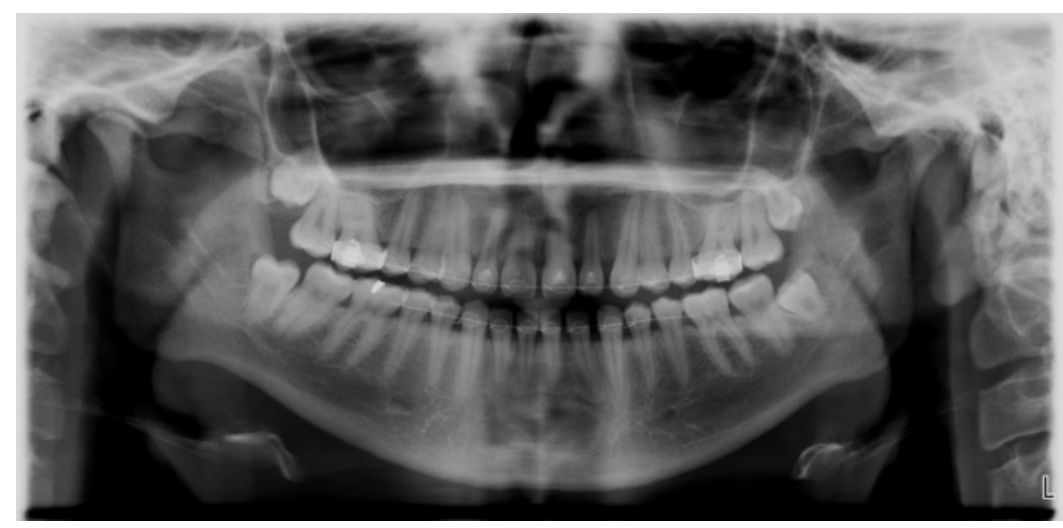

Figure 1. Panoramic radiograph. Oval radiolucent image in anterior-inferior sector.

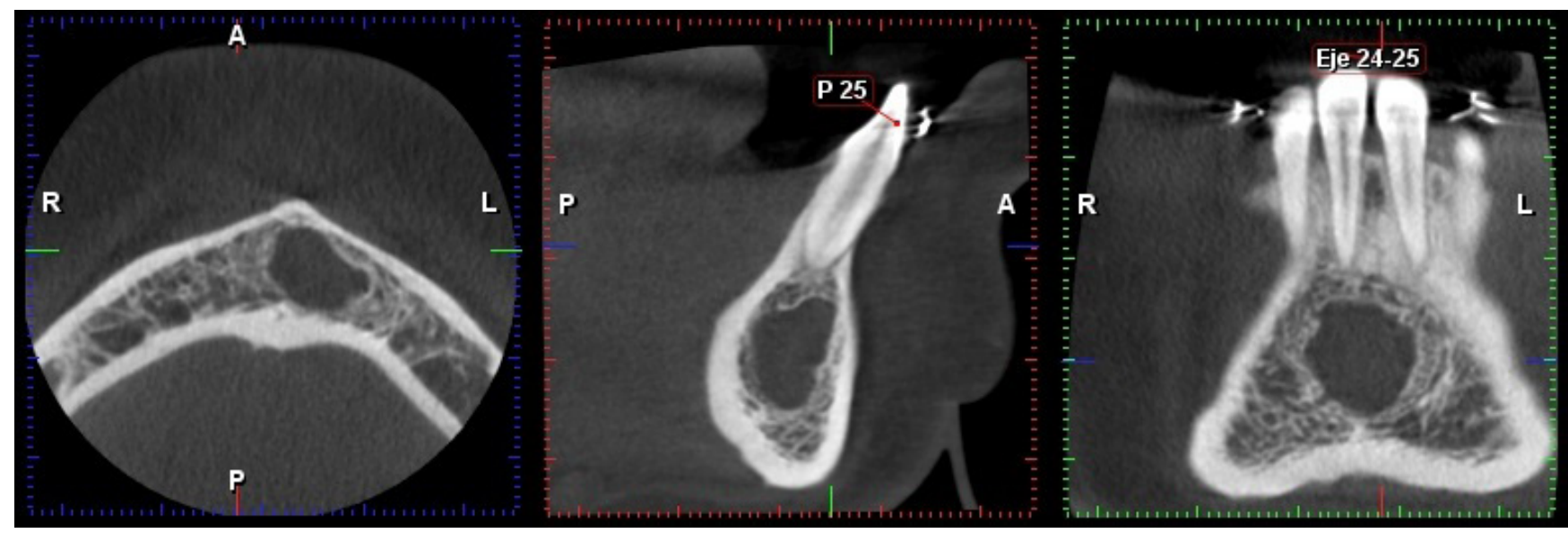

Figure 2. Cone beam computed tomography. 

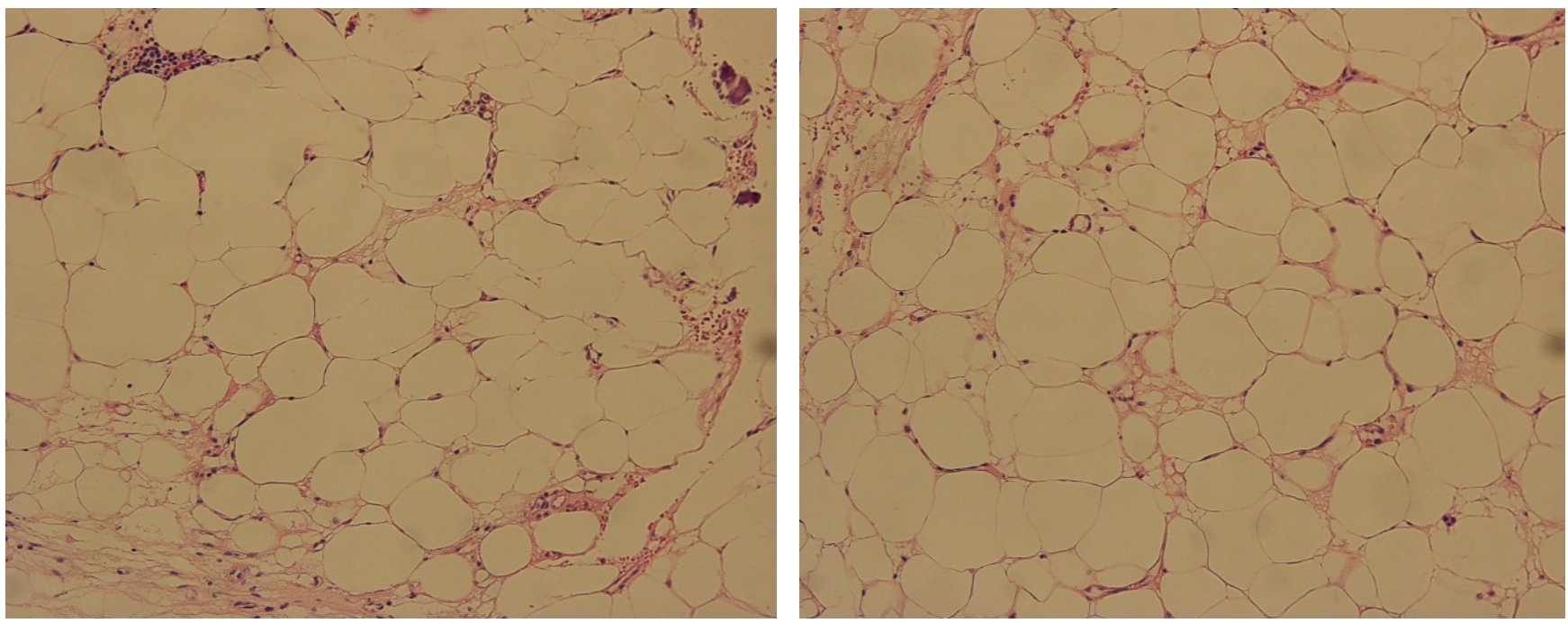

Figure 3. Adipose tissue without atypical features, surrounded by fibrous capsule.

\section{DISCUSSION}

Lipoma is a benign soft tissue tumor, which presents mature adipose tissue and affecting any body part. It is most commonly located in the subcutaneous level, where they are clinically presented individually, well circumscribed and with slow growth behavior. In contrast with this presentation at a subcutaneous tissue level, you can find intraosseous lipoma, which is a lot less frequent and one of the rarest primary benign bone tumors $(0.1 \%$ of all bone tumors) $[2,3,4]$.

Most intraosseous lipoma cases have been located in the diaphysis and epiphysis of long bones, as well as in calcaneus bones.

Specific anatomic locations within the oral and maxillofacial region include the parotid region, buccal mucosae, lips, submandibular region, tongue, palate, floor-of-mouth and vestibule. Infrequent locations of orofacial lipomas include the maxillary bones, especially the mandible [9].

Occasions are much more frequent at a mandibular level and since 1948 only 19 cases have been reported so its etiology and characteristics are difficult to specify $[2,4]$.

Although the number of reported cases is quite small, it becomes apparent that there is a slight predominance for females (1.4:1), within a 20 -65-year age range, and more commonly in their forties and fifties [2].

Clinically, most cases are asymptomatic and correspond to radiographic findings. However, depending on size, location and relationship to neighboring anatomical structures this lesion, can be detected by pain, increases in volume and neurological alterations $[1,2]$.

Radiographically, it is presented as unilocular or multilocular radiolucent areas with defined limits and sclerotic borders. In some cases, radiopaque zones have also been seen at the center of lesion areas $[1,3]$.
The defining histopathologic features of intraosseous lipoma are the early resorption of trabecular bone and the presence of fat. Milgram introduced the staging system for intraosseous lipoma, which is based on the ratio of viable to necrotic fat cells within the lesion. The progression of Milgram's three stages is produced by the increase in intralesional pressure as a result of cell proliferation. In the final stage, a formative reaction of bone tissue is generated along the periphery of the lesion [10].

There are no reported recurrence cases or malignant transformations in intraosseous lipomas affecting maxillary bones, however, two recurrence cases and four malignant transformations have been reported in long bones, for which the recommended treatment is surgery, either by curettage or local resection $[2,3]$.

Based on clinical and radiographic lesion characteristics, differential diagnosis should be made for cement osseous lesions, central giant cell granulomas, Keratocystic Odontogenic tumors, odontogenic myxomas, simple osseous cysts and osteoporotic defects [1,2].

Some authors sustain that the etiology of this lesion is associated with trauma, strokes and inflammation. In this case the patient did not report any accidents that could have been associated to the injury, but the patient was in orthodontic treatment more than a year before lesion diagnosis.

According to case revisions, only four have been presented in the anterior area, the Darling and Cakarer cases being most similar to the case being presented, in relation to gender, imaging, location and clinical presentation.

Due to low frequency and scarcity of intraosseous lipoma cases reported in literature, it is difficult to pinpoint presentation form and clinical behavior [4]. The treatment of choice is surgical enucleation of the lesion, since recurrences have not been reported in the literature [11]. 


\section{REFERENCES}

1. Cakarer S, Selvi F, Isler S C, Soluk M, Olgac V, Keskin C. Intraosseous lipoma of the mandible: A case report and review of the literature International Journal of Oral and Maxillofacial Surgery 2009;38(8): 900-2. https://doi.org/10.1016/j.ijom.2009.03.712

2. Basheer S, Abraham J, Shameena P, Balan A. Intraosseous lipoma if the mandible presenting as a swelling. J Oral Maxillofac Pathol 2013;Jan;17(1):126-128. https://doi.org/10.4103/0973-029X.110705

3. González-Pérez L M, Pérez-Ceballos J L, Carranza-Carranza A. Mandibular intraosseous lipoma: clinical features of a condylar location. International Journal Oral Maxillofacial Surgery 2010;39(6):617-20. https://doi.org/10.1016/j.ijom.2010.01.011

4. Santos de Freitas B, Yamamoto F P, Pontes F S, Fonseca F P, Rebelo H A, Pinto-Júnior, DD. Intraosseous lipoma of the mandible: A diagnostic challenge. Revista Odonto Ciencia 2011;26(2):182-6. https://doi. org/10.1590/S1980-65232011000200016

5. Vides-Lemus R, Astacio-Soria J N, Langenegger L C. Lipoma intraóseo del seno maxilar izquierdo. Primer caso reportado en el Salvador. Anales de otorrinolaringología mexicana 2012;57(3):177-9

6. Campbell RSD, Grainger AJ, Mangham DC, et al. Intraosseous lipoma: report of 35 new cases and a review of the literature. Skeletal Radiol 2003;32:209-22. https://doi.org/10.1007/s00256-002-0616-7
7. Öztekin Özgür, Argin Mehmet, Oktay Aysenur, Arkun Remide. Intraosseous lipoma: radiological findings. Radiol Bras [Internet]. 2008 Apr 41( 2 ): 81-6. https://doi.org/10.1590/S0100-39842008000200005

8. Man-Yee Chan, Po-Cheung Kwan, Ying-Lyung Hsiao, Chi-Sheng Cheng Chiu-Kwan Poon, Yong-Kie Wong. Intra-osseous Lipoma of the Mandible: Review of the Literature and Case Report. Clin J Oral Maxillofac Surg 2007;18:29-38.

9. Tettamanti L, Azzi L, Croveri F, Cimetti L, Farronato D, Bombeccari G Tagliabue A, Spadari F. Oral lipoma: Many features of a rare oral benign neoplasm. Head Neck Oncol 2014 June 10;6(3):21.

10. Srubiski A, Csillag A,Timperley $D$, et al. Radiological features of the intraosseous lipoma of the sphenoid. Otolaryngol Head Neck Surg 2011;144(4):617-2211.

11. Morais AL, Mendonça EF, de Alencar AHG, Estrela C. Intraosseous lipoma in the periapical region of a maxillary third molar. J Endod 2011;37:554-7. https://doi.org/10.1016/j.joen.2010.12.006 